East African Medical Journal Vol. 86 No. 9 September 2009

KNOWLEDGE GAPS, ATTITUDE AND BELIEFS OF THE COMMUNITIES ABOUT SICKLE CELL DISEASE IN EASTERN AND WESTERN UGANDA

A. L. Okwi, DMLT, MSc, Biomedical Scientist, W. Byarugaba, MSc, PhD, Associate Professor, Department of Pathology, Medical School, Makerere University, P.O. Box 7072, Kampala, Uganda, C. M. Ndugwa, MBChB, MMed, DTM \& H, Professor, Department of Paediatrics and Child Health, Medical School, Makerere University, P.O. Box 7072, Kampala, Uganda, A. Parkes, MSc, PhD, Senior Endocrinologist, Centre for Endocrine and Diabetes Sciences, Cardiff University, Cardiff CF14 4XN Wales, UK, M. Ocaido, MSc, PhD, Associate Professor, Department of Wildlife and Animal Resources, Faculty of Veterinary Medicine, Makerere University, P.O. Box 7062, Kampala, Uganda and J. K. Tumwine, MBChB, MMed, PhD, Professor, Department of Paediatrics and Child Health Medical School, Makerere University, P.O. Box 7062, Kampala, Uganda

Request for reprints to: Mr. A. L. Okwi, Department of Pathology, Medical School, Makerere University, P.O. Box 7072, Kampala, Uganda

\title{
KNOWLEDGE GAPS, ATTITUDE AND BELIEFS OF THE COMMUNITIES ABOUT SICKLE CELL DISEASE IN EASTERN AND WESTERN UGANDA
}

\author{
A. L. OKWI, W. BYARUGABA, C. M. NDUGWA, A. PARKES, \\ M. OCAIDO and J. K. TUMWINE
}

\begin{abstract}
Background:The management of sicklecell disease (SCD) has remained insurmountablein developing countries such as Uganda, because most communities are not aware of it. Objective: To determine knowledge gaps, attitudes and beliefs of the communities about sickle cell disease in Eastern and Western Uganda.

Design: Cross sectional descriptive study.

Setting: The districts of Sironko and Mbale in Eastern Uganda and Mbarara and Ntungamo in Western Uganda.

Subjects: Households, students and health workers.

Results: Household respondents from Eastern Uganda were more aware of SCD than those from Western $(p<0.001)$, with the majority reporting that they had seen more people with SCD in their communities than those from the West $(\mathrm{p}<0.001)$. Fewer $(<1.9 \%)$ believed SCD was due to witch craft. Eight per cent of household respondents in Eastern believed it was a curse from God compared to $2 \%$ in the West. Less than $18 \%$ of the household respondents knew they could have children with SCD and $(<52 \%)$ of health workers knew SCD screening methods. Fewer $(<14 \%)$ of the health workers had participated in screening. Less than $20 \%$ of the respondents knew their sickle cell status.

Conclusion: Respondents from Eastern Uganda were more aware of SCD than those from Western. Minority of the respondents knew their SCD status and few health staff knew how to screen it. There is need to sensitise communities and policy makers about prevention, screening and treatment of SCD.
\end{abstract}

\section{INTRODUCTION}

Beliefs, attitude and knowledge of the communities have contributed to the reduction and management of SCD. One study from USA found that improved understanding of SCD and constant assessment of parental beliefs about the disease was necessary for its management at home (1). Other studies found that communities where parents were more enlightened about SCD were more positive towards sickle cell screening (2). However, lack of screening programmes especially in areas with low prevalence of SCD, was associated with negative attitude of the communities towards screening (3).

According to the available literature on SCD in Uganda, no population based studies have been carried out to determine knowledge gaps, attitude and beliefs of communities and health workers about SCD and its detection.

This study was therefore done to determine the knowledge gaps, attitude and beliefs of the communities about SCD and its detection in Eastern and Western Uganda. The findings would be used by decision makers for policy formulation of sickle cell management programmes. 


\section{MATERIALS AND METHODS}

Study design and site: This was a cross sectional descriptive study which was carried out in Sironko and Mbale in Eastern and Mbarara and Ntungamo in Western Uganda. These districts were conveniently selected because these were districts which were involved in collaboration with innovations at Makerere University Committee (I@Mak.com), the founder of this project.

Study populations: These were households and secondary school students from both rural and urban setting and health professionals from health centres IV with paramedical training. These health professionals were chosen to avoid bais.

Sample size: The sample size of 571 household respondents was calculated using Kish and Leshlie formula (4). An acceptable error of 0.05 and 95\% confidence interval were used. Thenumber of villages in each district was calculated using probability proportions based on population size of the districts. Secondary schools and health sub-districts (health centers IVs) were selected using simple random sampling procedure.

Study procedure: Adults from households with children, were selected for interviews using a procedure according to World Health Organisation protocols. The data were collected using a structured questionnaire from interviewees after obtaining informed consent.

Students: The same procedureused to selectsecondary schools was used to select student participants from these schools. Twelve male and female students were randomly selected from each school and data were collected from them using a questionnaire.

Health workers: The paramedical health staff to be interviewed were not randomly selected because some health centres had as few as six eligible staff. Instead, all eligible staff at the health centre were personally interviewed after obtaining informed consent.

Data analysis: The data were entered and analysed using software package for social sciences 10.0 (SPSS 10.0) (6). The statistical difference of the knowledge gaps, attitude and beliefs in these study populations was compared using open source epidemiologic statistic programme for public health version 2.2.1 (OPENEPI) using $2 \times 2$ contingency tables (7). A p-value of $\leq 0.05$ was considered statistically significant.

Ethical clearance: Permission to carry out this study was sought from Faculty Research and Ethical Committee and Uganda National Council of Science and Technology (UNCST).

\section{RESULTS}

Two hundred and eighty rural and urban household respondents were interviewed from the study population of Mbale and Sironko in Eastern Uganda and 309 from the study population of Mbarara and Ntungamo in the West giving a total of 589 household respondents, which was a little $(1.03 \%)$ more than the minimum calculated sample size of 571 . Eighty eight students were interviewed from eastern and 85 from western giving a total of 173 students. Thirty four health workers respondents were interviewed in Eastern Uganda and 42 in Western giving a total of 76 health workers. These gave an overall total of 838 respondents (Table 1). A total of 214 female and 188 malerespondentswereinterviewed inEasternUganda, whilst two hundred and twenty nine female and 207 male respondents were interviewed from theWest. This gave an overall total of 838 respondents interviewed from both study populations (Table 3 ).

The recruited female and male participants, were aged between 18-60 years and were from urban and rural settings. The majority were peasants and students with primary and secondary education. The details of the socio-demographic characteristics of the respondents are as shown in Table 2.

Table 1

Number of respondents interviewed in Eastern and Western Uganda

\begin{tabular}{lccc}
\hline & $\begin{array}{c}\text { Mbale and Sironko } \\
\text { (Eastern region) }\end{array}$ & $\begin{array}{c}\text { Mbarara and Ntungamo } \\
\text { (Western region) }\end{array}$ & Total \\
\hline Household respondents & 280 & 309 & 589 \\
Student respondents & 88 & 85 & 173 \\
Health workers respondents & 34 & 42 & 76 \\
\hline Total & 403 & 436 & 838 \\
\hline
\end{tabular}


Table 2

The socio-demographic characteristics of all the respondents

\begin{tabular}{|c|c|c|c|c|c|}
\hline \multirow[t]{2}{*}{$\begin{array}{l}\text { Variable } \\
\text { Age: (18-60 years) }\end{array}$} & & \multicolumn{2}{|c|}{$\begin{array}{l}\text { Eastern } \\
(\mathrm{n}=402)\end{array}$} & \multicolumn{2}{|c|}{$\begin{array}{l}\text { Western } \\
(n=436)\end{array}$} \\
\hline & & No. & $(\%)$ & No. & $(\%)$ \\
\hline \multirow[t]{2}{*}{ Sex } & Male & 188 & 46.8 & 207 & 47.5 \\
\hline & Female & 214 & 53.2 & 229 & 52.5 \\
\hline \multirow[t]{5}{*}{ Education } & Informal & 22 & 5.5 & 24 & 5.5 \\
\hline & Primary & 129 & 51.9 & 155 & 35.6 \\
\hline & Secondary & 192 & 47.8 & 157 & 36.0 \\
\hline & Tertiary & 51 & 12.7 & 68 & 15.6 \\
\hline & University & 8 & 2.0 & 32 & 7.4 \\
\hline \multirow[t]{4}{*}{ Occupation } & Employed & 82 & 20.4 & 120 & 27.6 \\
\hline & Student & 121 & 30.1 & 118 & 27.5 \\
\hline & Peasant & 141 & 35.1 & 99 & 22.7 \\
\hline & Self employed & 58 & 14.4 & 209 & 47.9 \\
\hline \multirow[t]{5}{*}{ Religion } & Catholic & 85 & 21.1 & 174 & 39.9 \\
\hline & Protestant & 142 & 35.3 & 188 & 43.1 \\
\hline & Muslim & 111 & 27.6 & 18 & 4.1 \\
\hline & Orthodox & 4 & 1.0 & 7 & 1.6 \\
\hline & Reedemed & 10 & 2.5 & 16 & 3.7 \\
\hline \multirow[t]{2}{*}{ Location } & Rural & 215 & 53.5 & 237 & 54.4 \\
\hline & Urban & 187 & 46.5 & 199 & 45.6 \\
\hline \multirow[t]{4}{*}{ Distance to health centre } & $<3 \mathrm{~km}$ & 115 & 28.6 & 99 & 22.7 \\
\hline & $3-10 \mathrm{~km}$ & 138 & 34.3 & 103 & 23.6 \\
\hline & $>10 \mathrm{~km}$ & 81 & 20.1 & 50 & 11.5 \\
\hline & Uncommitted & 68 & 16.9 & 184 & 42.2 \\
\hline
\end{tabular}

Knowledge gaps: Seventy three per cent of the household respondents from Eastern Uganda were aware of SCD compared to 59\% from the West ( $\mathrm{p}<0.001)$ (OR 1.85: 95\% CI: 1.31-2.62). Forty nine percent of household respondents from the East claimed that persons with SCD had been detected in their communities compared to only $20 \%$ from the West $(\mathrm{p}<0.001)$ (OR 3.93: 95\% CI: 2.49-6.20). Forty five per cent of the students from the East claimed that persons with SCD disease had been detected in their communities compared to $18 \%$ from the West $(\mathrm{p}<0.001)$ (OR 3.94: 95\% CI: 1.73-8.98). Fifty two percent of the health workers from the East knew sickle cell disease screening methods compared to
$50 \%$ from the West ( $\mathrm{p}>0.05$ ) (OR 1.07: 95\% CI: 0.392.93). Notably, $14 \%$ of the health staff from the East screened for SCD compared to $9 \%$ from the West. Less than $20 \%$ of the respondents knew their sickle cell status (Table 3).

Beliefs: Eight per cent of the household respondents in Sironko and Mbale believed that SCD was a punishment from God compared to $2 \%$ from Mbarara and Ntungamo. Seventy eight per cent of the household respondents from the East believed SCD could be prevented by premarital screening compared to $74 \%$ from the west ( $p>0.05$ ) (OR 1.2: 95\% CI: 0.77- 1.94) (Table 4). 
Table 3

Knowledge of respondents about SCD in Eastern and Western Uganda

\begin{tabular}{|c|c|c|c|c|c|c|c|}
\hline & \multicolumn{2}{|c|}{ Eastern } & \multicolumn{2}{|c|}{ Western } & \multirow{2}{*}{$\begin{array}{l}\text { Odds } \\
\text { Ratio }\end{array}$} & \multirow[t]{2}{*}{$95 \% \mathrm{CI}$} & \multirow[t]{2}{*}{ P-value } \\
\hline & No. & $(\%)$ & No. & $(\%)$ & & & \\
\hline Households (non- students) & \multicolumn{2}{|c|}{$\mathrm{n}=280100$} & \multicolumn{3}{|c|}{$n=309100$} & & \\
\hline $\begin{array}{l}\text { Awareness about sickle cell } \\
\text { disease }(S C D)\end{array}$ & 204 & 72.9 & 183 & 59 & 1.85 & $1.31-2.62$ & $<0.001$ \\
\hline \multicolumn{8}{|l|}{ Only for those aware $(n=204)$} \\
\hline $\begin{array}{l}\text { Seen persons with SCD in } \\
\text { community }\end{array}$ & 100 & 49.0 & 36 & 19.7 & 3.93 & $2.46-6.20$ & $<0.001$ \\
\hline Knew they could possibly & & & & & & & \\
\hline have children with SCD & 30 & 14.7 & 32 & 17.4 & 1.04 & $1.61-1.76$ & 0.887 \\
\hline Knows his/her SC status & 5 & 2.5 & 2 & 1.1 & 2.78 & $0.55-20.9$ & 0.234 \\
\hline Students & \multicolumn{2}{|c|}{$\mathrm{n}=8892$} & \multicolumn{2}{|c|}{$\mathrm{n}=8589$} & & & \\
\hline $\begin{array}{l}\text { Awareness about sickle cell } \\
\text { disease (SCD) }\end{array}$ & 62 & 70.5 & 50 & 58.8 & 1.67 & $0.89-3.13$ & 0.114 \\
\hline \multicolumn{8}{|l|}{ Only those aware ( $\mathrm{n}=62)$} \\
\hline $\begin{array}{l}\text { Seen persons with SCD in } \\
\text { his/her community }\end{array}$ & 28 & 45.2 & 9 & 18 & 3.94 & $1.73-8.98$ & $<0.001$ \\
\hline Knows his/her SC status & 1 & 1.6 & 0 & 0 & - & - & 0.052 \\
\hline Health workers & \multicolumn{2}{|c|}{$\mathrm{n}=3471$} & \multicolumn{3}{|c|}{$\mathrm{n}=42 \quad 88$} & & \\
\hline $\begin{array}{l}\text { Awareness about sickle cell } \\
\text { disease }(S C D)\end{array}$ & 29 & 85.3 & 32 & 76.2 & 1.81 & $0.55-5.93$ & 0.342 \\
\hline $\begin{array}{l}\text { Knows can be managed if } \\
\text { diagnosed early }\end{array}$ & 27 & 79.4 & 33 & 78.6 & 1.05 & $0.35-3.20$ & 0.936 \\
\hline \multicolumn{8}{|l|}{ Only for those aware $(n=29)$} \\
\hline $\begin{array}{l}\text { Correctly know screening } \\
\text { method (s) }\end{array}$ & 15 & 51.7 & 16 & 50 & 1.07 & $0.39-2.93$ & 0.896 \\
\hline Screen for sickle cell disease & 4 & 13.8 & 3 & 9.4 & 1.55 & $0.32-7.58$ & 0.617 \\
\hline Knows his/her SC status & 4 & 13.8 & 2 & 6.3 & 2.4 & $0.41-14.21$ & 0.366 \\
\hline Came across SCD patients & 20 & 69.0 & 10 & 31.3 & 4.57 & $1.71-12.24$ & 0.002 \\
\hline
\end{tabular}

Table 4

Beliefs of respondents about SCD in Eastern and Western Uganda

\begin{tabular}{|c|c|c|c|c|c|c|c|}
\hline & \multicolumn{2}{|c|}{ Eastern } & \multicolumn{2}{|c|}{ Western } & \multirow{2}{*}{$\begin{array}{l}\text { Odds } \\
\text { Ratio }\end{array}$} & \multirow[t]{2}{*}{$95 \% \mathrm{CI}$} & \multirow[t]{2}{*}{ P-value } \\
\hline & No. & $(\%)$ & No. & $(\%)$ & & & \\
\hline $\begin{array}{l}\text { Households (only for } \\
\text { those aware of SCD) }\end{array}$ & \multicolumn{2}{|c|}{$\mathrm{n}=204$} & \multicolumn{3}{|c|}{$\mathrm{n}=183$} & & \\
\hline \multicolumn{8}{|l|}{ Causes of SCD } \\
\hline Natural & 59 & 28.9 & 72 & 39.3 & 0.88 & $0.60-1.30$ & 0.518 \\
\hline Punishment from God & 17 & 8.3 & 4 & 2.1 & 4.92 & $1.73-17.22$ & 0.002 \\
\hline Witchcraft & 4 & 1.9 & 3 & 1.6 & 1.48 & $0.30-8.0$ & 0.63 \\
\hline Acquired from parents & 117 & 57.3 & 94 & 51.3 & 1.64 & $1.17-2.30$ & 0.004 \\
\hline $\begin{array}{l}\text { Can be prevented by } \\
\text { screening before marriage }\end{array}$ & 158 & 77.5 & 135 & 73.8 & 1.2 & $0.77-1.94$ & 0.403 \\
\hline
\end{tabular}




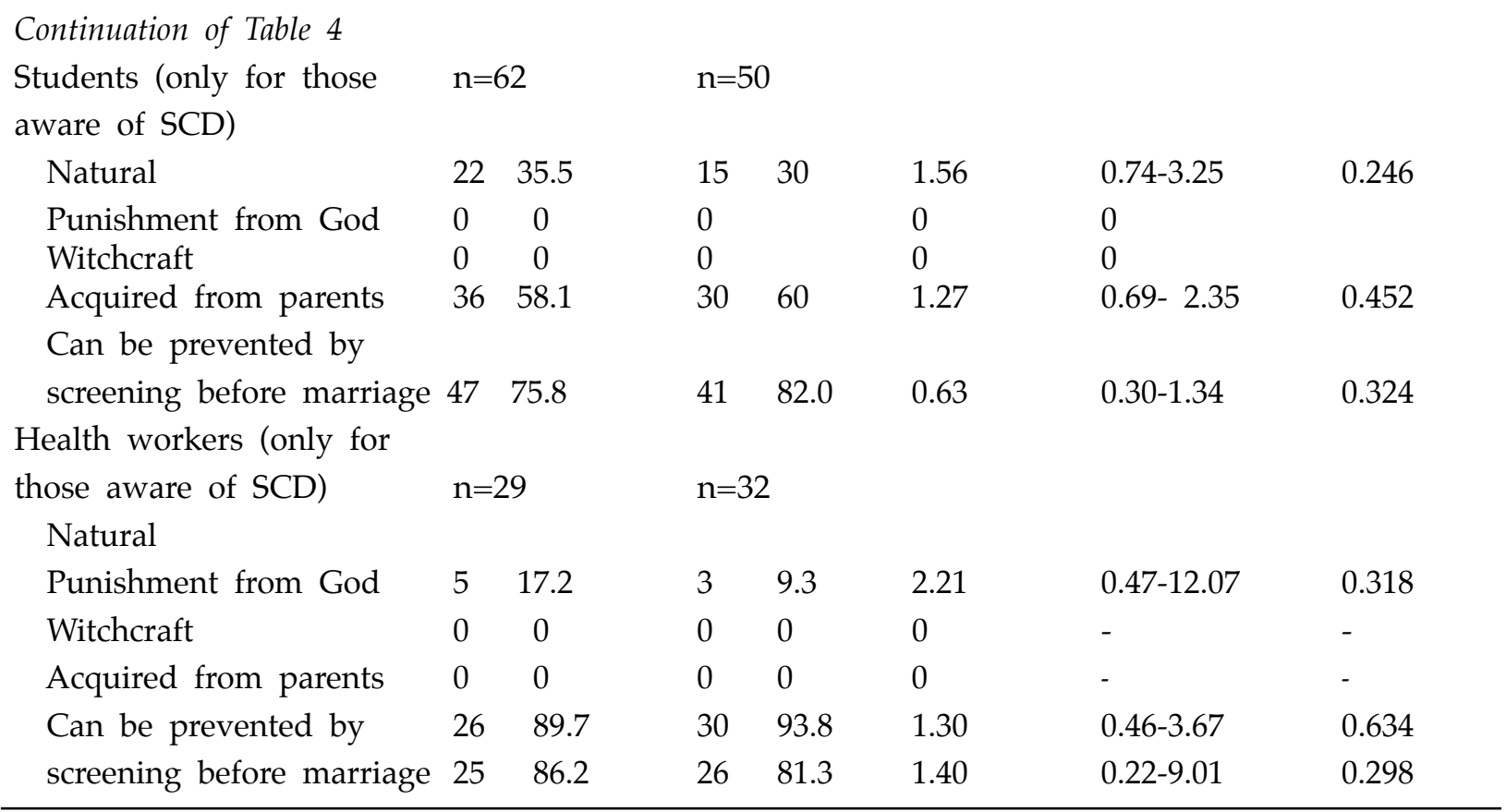

Attitudes: Fifty eight per cent of the respondents from the East felt sympathetic about patients' illness compared to $67 \%$ from the West. Eleven per cent and $3 \%$ of the respondents from the East and the West felt embarrassed respectively ( $\mathrm{p}<0.001)$ (OR 4.5: 95\% CI:, 1.65-12.27). Thirty eight per cent felt depressed about patients' illness from the East compared to $22 \%$ from the West ( $\mathrm{p}<0.001$ ) (OR 2.25: 95\% CI: 1.42-3.57). Over $85 \%$ of the respondents were willing to be screened for SCD, although $8 \%$ of the respondents from the East were not willing to be screened compared to $12 \%$ from the West (Table 5).

Table 5

Attitude of respondents about SCD in Eastern and Western Uganda

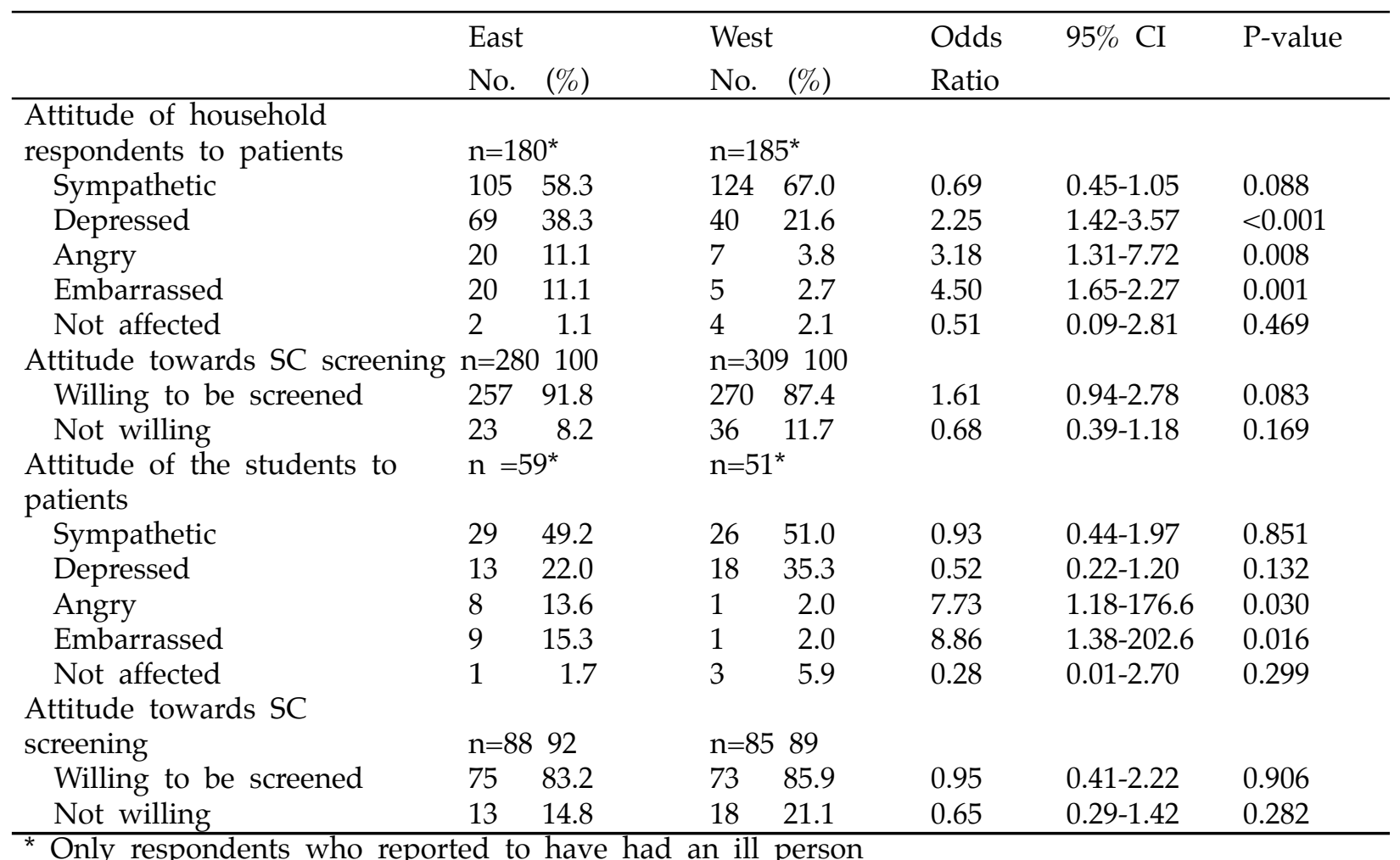


Sources of information about health: The main sources of information of the household respondents about health, in descending order, were radio, health visitors, community, newspapers and lastly television, whilst for the student respondents they were health visitors, radio, television and community (Table 6).

Table 6

The main sources of information of the household and student respondents about health in Eastern and Western Uganda

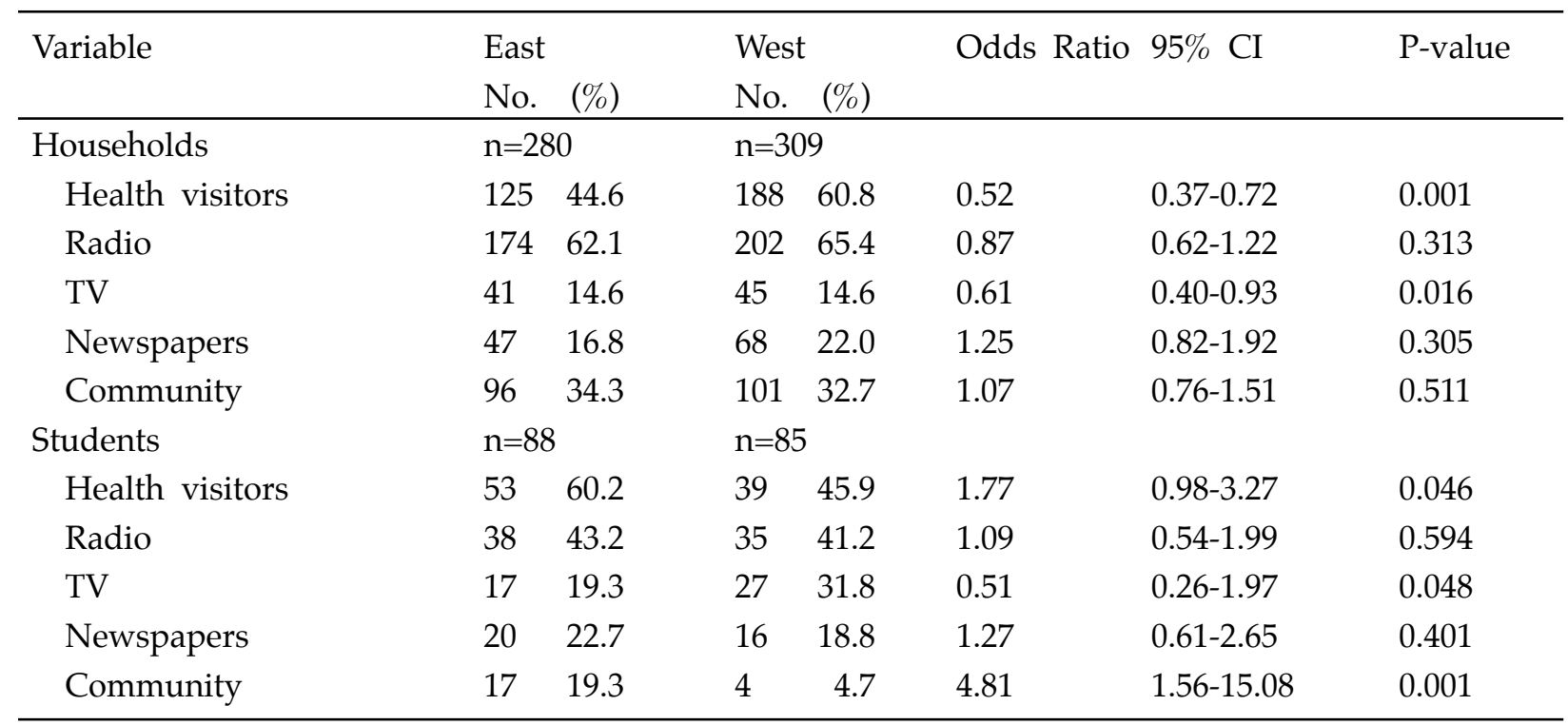

The main sources of information of the rural household respondents about health were mostly health visitors and radio whilst the urban respondents were more privileged to watch television and read news papers besides getting information from health visitors and community (Table 7).

Table 7

The main sources of information of the rural and urban household respondents about health in Eastern and Western Uganda

\begin{tabular}{|c|c|c|c|c|c|c|c|c|}
\hline \multirow[t]{2}{*}{ Variable } & \multicolumn{2}{|c|}{ Rural } & \multicolumn{2}{|c|}{ Urban } & \multirow{2}{*}{\multicolumn{2}{|c|}{ Odds Ratio }} & \multirow[t]{2}{*}{$95 \% \mathrm{CI}$} & \multirow[t]{2}{*}{ P-value } \\
\hline & No. & $(\%)$ & No & $(\%)$ & & & & \\
\hline Eastern & \multicolumn{2}{|c|}{$\mathrm{n}=140$} & \multicolumn{2}{|c|}{$\mathrm{n}=140$} & & & & \\
\hline Health visitors & 75 & 53.6 & 50 & 35.7 & 2.08 & & $1.29-3.37$ & 0.001 \\
\hline Radio & 75 & 53.6 & 99 & 70.7 & 0.48 & & $0.29-0.78$ & 0.001 \\
\hline TV & 12 & 8.6 & 29 & 20.7 & 0.40 & & $0.17-0.73$ & 0.002 \\
\hline Newspapers & 17 & 12.1 & 30 & 21.4 & 0.51 & & $0.27-0.97$ & 0.002 \\
\hline Community & 18 & 12.9 & 58 & 41.4 & 0.21 & & $0.11-0.39$ & 0.001 \\
\hline Western & \multicolumn{2}{|c|}{$\mathrm{n}=150$} & \multicolumn{2}{|c|}{$n=159$} & & & & \\
\hline Health visitors & 97 & 64.7 & 91 & 57.2 & 1.37 & & $0.86-2.16$ & 0.09 \\
\hline Radio & 120 & 80.0 & 82 & 51.6 & 3.75 & & $2.26-6.24$ & 0.001 \\
\hline TV & 10 & 6.7 & 42 & 31.8 & 0.06 & & $0.02-0.19$ & 0.001 \\
\hline News papers & 17 & 11.3 & 51 & 26.4 & 0.27 & & $0.15-0.50$ & 0.401 \\
\hline Community & 41 & 27.3 & 60 & 37.7 & 0.62 & & $0.38-1.0$ & 0.03 \\
\hline
\end{tabular}




\section{DISCUSSION}

The study sought to determine the knowledge gaps, attitude and beliefs aboutSCD from the communities in Mbale and Sironko in Eastern and Mbarara and Ntungamo in Western Uganda. Whereas there was increased awareness about SCD among household communities in the Eastern region compared to those in the West, as expected, these findings could have been influenced by differences in the prevalence of SCD in these study populations $(8,9)$. These results were similar to those by Armeli et al (10) who noted that people from areas of high prevalence of SCD were more likely to be more aware about it than those from areas of low prevalence.

However, there was no statistical difference between the student respondents from Eastern and Western Uganda as far as awareness of SCD was concerned. This finding probably indicated that the awareness of SCD between the students respondents in these regions were more sensitive to education background than the prevalence of SCD.

Similarly, the awareness about SCD in Western region appeared to have been influenced by both the location and education background of the household respondents other than prevalence. This was particularly noted among the urban household respondents whose awareness about SCD was high probably because they had secondary, tertiary and university education, watched televisions and read news papers unlike their rural counter parts who mostly had primary education and whose main sources of information about health were health visitors and radio.

While the majority of the respondents new sickle cell as 'siko cello', which we believe was coined from English word sickle cell, few respondents had varying understanding of what sickle cell was with those from Eastern Uganda calling it'Enkaka' meaning yellow fever and Western Uganda communities calling it 'Okupumpura (plague like), Binyoro (yaws) and Kisipi (herpes zoster). This observation probably explains why sickle cell still remains enigmatic among members in the communities.

The beliefs about SCD remain diverse in many communities as was seen in this study. While the majority believed SCD was acquired from parents, a few believed that it was "a curse from God", and was due to witchcraft. These observations are in agreement with the study by Ohaeri and Shokundi (11) which found that while the majority of the respondents believed that SCD was natural/genetic, a few believed it was "curse from God" and witch craft. These findings are also similar to the study by Treadwell and Mc Clough (12) which noted that most of the respondents correctly believed that SCD was inherited from parents, although a few believed that it was acquired through blood transfusion and was contagious.
Whilst a few studies found positive attitude towardssickle cell screening to belinked to improved management of SCD, the findings of the current study indicated that the although the majority of the respondents had high attitude towards sickle cell screening many did not know their sickle cell status. Besides, most of the health staff lacked skills on sickle cell screening methods, which probably explains why most of the district health centres were not screening for SCD and why most of these respondents had not been screened for SCD (3) and therefore did not know their sickle cell status.

Limitation of the study: Since the selection of the study districts was done using convenient sampling, the rest of the districts in Eastern and Western Uganda were not given an equal chance to be represented. So the currentresults can not be generalised as representative of the whole Eastern or Western Uganda.

Conclusion and recommendations: Respondents from Eastern were more aware about SCD than those from Western Uganda. Some believed it was a 'curse from God' or that it was due to witch craft. Most of the health centres were not screening for SCD and the majority of the respondents were not aware of their sickle cell status. There is therefore need to sensitise communities and policy makers about prevention, screening and management of SCD.

\section{ACKNOWLEDGEMENTS}

We thank Innovations at Makerere University Committee for sponsorship. We are also grateful to the district leaders, in charge of the health centres and respondents for their cooperation during this study. We thank Mr. Ronald Kiguba for assistance.

\section{REFERENCES}

1. Elliot, V. Morgan, S. Days, S. Mollerup, L.S. and Wang, W. Parental health beliefs and compliance with prophylactic penicillin administration in children with sickle cell disease. J. Pediat. Hemat/Onco. 2001; 23: 112-116.

2. Elizabeth, C. and Fried, M.R. Parental attitude and beliefs regarding the genetic testing of children. Comm. Genetics. 2005; 8: 94-102.

3. Cynthia, G. National Health Service for sickle cell screening and Thalassaemia screening programme. 2004. http://www.phm.umds.ac.uk/heamscreening/ Documents/ServicesReport.pdf. Friday June 2007.

4. Kirkwood, B.R.Calculation of required samplesize.In: Essentials and Medical Statistics, Blackwell-Science LN London 1988.

5. Henderson, R.H. and Sundareson, T. Cluster sampling to assess immunization coverage. Review of experience with a simplified sampling method. Bull. World Health Org. 1982; 60: 253-260. 
6. SPSS Advanced Statistics 10.1. Chicago: SPSS Inc, 2000.

7. Open Source Epidemiologic Statistics from Public Health Version 2.2.1 http://www.openepi.com/ Menu/EpiMenu.htm 6th April 2008.

8. Trowel, C. Sickle cell anaemia. East Afr. Med. J. 1945; 12: $34-45$.

9. Lehmann, H. and Raper, A.B. Distribution of sickle cell trait in Uganda, and its ethnological significance. Nature. 1949; 164: 494-495.

10. Armeli, C. Robbins, S.J. and Eunup, D. Comparing knowledge of $\beta$ - thalassaemia in samples of Italian,
Italian-Americans and Non-Italians. Amer. J. Gen. Couns. 2005; 14: 1123-1125.

11. Ohaeri, J.U. and Shokundi,W.A.Attitudes and beliefs of relatives of patients with sickle cell disease. East Afr. Med. J. 2001; 78: 174-178.

12. Treadwell, M.J. and McClough, L.V.Using qualitative and quantitative strategies to evaluate knowledge and perceptions about sickle cell disease and sickle cell trait. J. National Med. Assoc. 2006; 98: 704-710. 